\title{
Article
}

\section{Upaya Pemerintah Kecamatan Dalam Melestarikan Seni Tradisional}

\author{
Ronal Dison ${ }^{1 *}$, Hasanusi ${ }^{2}$
}

This article is an open access article distributed under the terms and conditions of the Creative Commons Attribution-ShareAlike 4.0 International (CC BY SA ) License (https://creativecommo ns.org/licenses/bysa/4.0/).

\section{Jurnal Politik dan} Pemerintahan Daerah ISSN 2686-2271

Fakultas Ilmu Sosial dan Ilmu Politik, Universitas Muara Bungo Jl. Diponegoro No. 27, Muara Bungo-Jambi, (0747) 323310

\author{
1 Program Studi Ilmu Pemerintahan Fakultas Ilmu Sosial Dan Ilmu Politik, Universitas \\ Muara Bungo, Kabupaten Bungo, Provinsi Jambi \\ ${ }_{2}^{2}$ Program Studi Ilmu Pemerintahan Fakultas Ilmu Sosial Dan Ilmu Politik, Universitas \\ Muara Bungo, Kabupaten Bungo, Provinsi Jambi \\ * Correspondence Author: ronal dison@yahoo.com
}

Abstract: This study aims to determine the Efforts of the Tanah Sepenggal District Government in Preserving Traditional Arts in Tanah Sepenggal District, Kab. Bungo. The second objective is to find out the obstacles faced by the Tanah Sepenggal District Government in Preserving Traditional Arts. And the third goal is to find out how the Tanah Sepenggal District Government solves the obstacles that exist in Preserving Traditional Arts. This study uses two methods, namely secondary data and related sources. The results of this study are that the efforts of the Tanah Sepenggal District Government in Preserving Traditional Arts in Tanah Sepenggal District are by conducting socialization about Traditional Arts by involving the surrounding community. In this case, the Tanah Sepenggal District Government cooperates with the Art Studio and Village Apparatus. We from the Village Apparatus Preserve Traditional Art by participating in an Art Performance organized by the Tanah Sepenggal District Government which was held on November 9, 2017. By holding an Art Performance, we can increase public interest in Traditional Art, so that Traditional Art in Tanah Sepenggal District preserved and not forgotten by the local community. So we as the people of Tanah Sepenggal District participate in Preserving Traditional Art so that Traditional Art is not forgotten by the local community, and remains in demand by future generations.

Keywords: Quality Human Resources Empowerment

Abstrak: Penelitian ini bertujuan untuk mengetahui Upaya Pemerintah Kecamatan Tanah Sepenggal dalam Melestarikan Seni Tradisional di Kecamatan Tanah Sepenggal Kab. Bungo. Tujuan kedua untuk mengetahui hambatan yang di hadapi oleh Pemerintah Kecamatan Tanah Sepenggal dalam Melestarikan Seni Tradisional. Dan tujuan ketiga untuk mengetahui cara Pemerintah Kecamatan Tanah Sepenggal menyelesaikan hambatan yang ada dalam Melestarikan Seni Tradisional. penelitian ini menggunakan dua Metode yaitu Data Sekunder dan sumber-sumber yang terkait. Hasil penelitian ini bahwa Upaya Pemerintah Kecamatan Tanah Sepenggal dalam Melestarikan Seni Tradisional di Kecamatan Tanah Sepenggal yaitu dengan mengadakan sosialisasi tentang Seni Tradisional dengan melibakan masyarakat sekitarnya. Dalam hal ini Pemerintah Kecamatan Tanah Sepenggal berkerja sama degan Sanggar Seni, dan Perangkat-Perangkat Desa. Kami dari Perangkat Desa Melestarikan Seni Tradisional dengan cara mengikuti Pentas Seni yang di selenggarakan oleh Pemerintah Kecamatan Tanah Sepenggal yang di adakan pada tanggal 09 November 2017. Dengan mengadakan Pentas Seni dapat meningkatkan minat masyarakat terhadap Seni Tradisional, sehingga Seni Tradisional yang ada di Kecamatan Tanah Sepenggal tetap Terlestarikan dan tidak terlupakan oleh kalangan masyarakat setempat. Jadi kami selaku masyarakat Kecamatan Tanah Sepenggal ikut serta dalam 
Melestarikan Seni Tradisional sehingga Seni Tradisional tidak dilupakan oleh masyarakat setempat, dan tetap diminati oleh generasi-generasi yang akan datang.

Kata Kunci : Pemberdayaan Sumberdaya Manusia Yang Berkualitas

\section{Pendahuluan}

Indonesia memiliki budaya yang bermutu tinggi dan beraneka ragam, minsalnya musik daerah. Keragaman musik daerah dipengaruhi oleh budaya dan adat istiadat setempat yang beraneka ragam. Hal itu yang menambah kekayaan budaya kita. Selain itu Indonesia merupakan Negara kepulauan yang terdiri dari banyak pulau dan memiliki berbagai macam suku bangsa, bahasa, adat istiadat atau yang sering kita sebut kebudayaan. keanekaragaman budaya yang terdapat di Indonesia merupakan suatu bukti bahwa Indonesia merupakan Negara yang kaya akan budaya (Wijiono, 2009),

Seni budaya merupakan karya seni estetis, artistic, dan kreatif yang berakar pada norma, nilai, perilaku, dan produk seni budaya suatu bangsa yang terwujud dalam kesenian (Wulansari, 2017). Tidak bisa kita pungkiri, bahwa kebudayaan daerah merupankan faktor utama berdirinya kebudayaan yang lebih global, yang bisa kita sebut dengan kebudayaan nasional. Maka atas dasar itulah segala bentuk kebudayaan daerah akan sangat berpengaruh terhadap budaya nasional, begitu pula sebaliknya kebudayaan nasional yang bersumber dari kebudayaan daerah, akan sangat berpengaruh pula terhadap kebudayaan daerah / kebudayaan lokal. Kebudayaan merupakan suatu kekayaan yang sangat bernilai karena selain merupakan cirri khas dari suatu daerah juga menjadi lambang dari kepribadian suatu bangsa atau daerah.

Negara Indonesia merupakan negara yang unik dengan banyak keragaman hayati dan kebinekaan budaya yang sangat tinggi (Iskandar, 2017). Seni sudah menjadi salah satu bagian dalam kehidupan manusia dari zaman kezaman dari masa prasejarah hingga sekarang, keberadaan seni sangat melekat dalam setiap sendi kehidupan dan jiwa manusia hingga tidak dapat terpisahkan sampai saat ini. Dengan adanya keterikatan antara seni dan manusia, seni semakin menjadi suatu hal yang menarik atau yang terpopuler bagi sebagian besar orang baik dari Negara dan suku manapun (www.google.com/amp/s/ilmuseni.com).

Masyarakat sangat membutuhkan pemuda untuk ikut serta dalam seni tradisional dikarenakan pemuda adalah generasi penerus bangsa. Sebagai penerus bangsa, pemuda diharapkan memiliki rasa nasionalisme yang tinggi. Sehingga dapat mempertahankan identitas bangsa, khususnya dalam kesenian tradisional. Pada bidang seni tradisional, pemuda memiliki peran yang cukup penting, yaitu untuk menggali seni tradisional dan meningkatkan minat rakyat terhadap seni tradisional itu sendiri. Sebab, tanpa adanya keinginan pemuda untuk terus mempelajari dan menigkatkan minat rakyat terhadap seni tradisional, baik dalam hal tarian, pakaian, alat music, lagu, dll maka seni tradisional Indonesia akan menghilang. Padahal seni tradisional merupakan bagian dari budaya Indonesia dan salah satu kekayaan Indonesia.

Pada faktanya dari waktu ke waktu minat rakyat semakin berkurang terhadap budaya Indonesia, terutama dalam seni tradisional. Saat ini, generasi muda lebih suka mempelajari dance dibandingkan tarian daerah, mendengar music barat atau lagu korea dibandingkan mendengarkan musik yang memiliki unsur tradisional, dan mempelajari alat music moderen dibandingkan belajari alat music tradisional. Tidaklah aneh apabila tarian dan lagu daerah Indonesia sempat di klaim oleh Negara lain. Seharusnya pemudalah yang memiliki minat tinggi terhadap 
kebudayaan indonesia dan mau mengembangkannya dengan kreatifitas dan pengetahuan yang dimiliki.

Dengan adanya seni tradisional masyarakat akan dapat menciptakan kehidupan yang harmonis dan dapat mengaspresiasikan orang lain untuk melakukan hal-hal yang kreatif. Seni tradisional merupakan suatu kebutuhan dasar, keinginan dan juga hiburan yang senantiasa diharapkan masyarakat dalam melaksanakan aktifitas sehari-hari. Oleh karenanya masyarakat sangat mendambakan adanya seni tradisional diruang lingkup mereka, dengan itu mereka biasa melakukan hal-hal yang kreatif dalam kesenian.

Untuk menciptakan dan menjaga agar masyarakat tetap membudidayakan dan melestarikan seni tradisional di seluruh pelosok - pelosok yang ada di Indonesia, terutama di Kecamatan Tanah Sepenggal. Yakni Pemerintah Kecamatan Tanah Sepenggal mengayomi masyarakatnya agar tetap melaksanakan yang namanya seni tradisional.

Sebab di Kecamatan Tanah Sepenggal ini yang namanya seni tradisional hampir terlupakan oleh masyarakat setempat seperti: (1) Batauh (2) Robana (3) Orkes Gambus dll. Tetapi Pemerintah Kecamatan Tanah Sepenggal tersebut mengadakan lomba Batauh, Robana, dan Orkes Gambus. Tepatnya di Pasar Lubuk Landai guna untuk mempertahankan budaya - budaya lama yang hampir terlupakan oleh masyarakat setempat.

Dikarenakan seni tradisional merupakan warisan nenek moyang maka sesuatu yang tradisonal ditentukan oleh budaya tempat dimana ia lahir. Sesuatu yang tradisional bukan berarti sesuatu yang jelek. Sebaliknya sesuatu menjadi tradisi karena dianggap paling tepat dan telah teruji keefektifan dan keefisienannya oleh suatu kelompok masyarakat pada masa dan tempat tertentu, bahkan kemudian diwariskan kepada anak cucunya.

Tabel 1. Jenis - Jenis Tari Tradisional Kecamatan Tanah Sepenggal

\begin{tabular}{c|c|c|c} 
NO & NAMA & JENIS & STATUS \\
& & & \\
1 & Krinok / Tauh & Tari & Eksis \\
2 & Rabana & Tari & Tidak Eksis \\
3 & Orkes Gambus & Musik & Tidak Eksis \\
4 & Mainang & Tari & Tidak Eksis
\end{tabular}

Sumber : Data Kecamatan Tanah Sepenggal, 2017

Ia terlihat kuno atau tidak efektif dan efisien lagi ketika sudah muncul sesuatu yang baru yang lebih baik serta lebih efektif dan efisien. Meskipun demikian seni tradisional tidaklah buruk bahkan sangat indah dan harus tetap dijaga kelestariannya. Seni tradisional sebagai identitas bangsa Indonesia harus dipertahankan, salah satunya dengan cara meningkatkan minat pemuda terhadap seni tradisonal.

Adapun anggaran Pentas Seni Tradisional (PENSI) yang di adakan oleh Pemerintah Kecamatan Tanah Sepenggal tersebut adalah sebagai berikut.

Tabel 2. Daftar Anggaran Pentas Seni Tradisional Kecamatan Tanah Sepenggal

\begin{tabular}{l|l|c} 
No & \multicolumn{1}{|c|}{ Nama Desa } & Jumlah \\
1 & Desa Teluk Pandak & 5.000 .000 \\
2 & Desa Empelu & 5.000 .000 \\
3 & Desa Tanah Bekali & 5.000 .000
\end{tabular}




\begin{tabular}{l|l}
4 & Desa Lubuk Landai \\
5 & Desa Sungai Gambir \\
6 & Desa Pasar Rabu \\
7 & Desa Tenam \\
8 & Desa Telentam \\
9 & Desa Candi \\
10 & Desa Tanjung \\
& Total Jumlah
\end{tabular}

5.000 .000

5.000 .000

5.000 .000

5.000 .000

5.000 .000

5.000 .000

5.000 .000

50.000 .000

Sumber: data kecamatan tanah sepenggal, 2017

Anggaran tersebut diambil dari seluruh desa yang ada di kecamatana tanah sepenggal berdasarkan hasil kesepakatan atau hasil musyawaroh pemerintah kecamatan dengan seluruh rio di kecamatan tanah sepenggal. Hal ini dilakukan untuk melestarikan seni tradisional yang ada di kecamatan tanah sepenggal, dikarenakan seni tradisional yang ada di kecamatan tanah sepenggal hampir dilupakan oleh masyrakat setempat. Maka dari itu lah Pemerintah Kecamatan membuat kebijakan untuk Melestarikan Seni Tradisional dengan cara mengadakan Pentas Seni setiap tahun sekali, Hal ini berdasarkan hasil kesepakatan atau hasil musyawarah Pemerintah Kecamatan dengan seluruh Rio yang ada di Kecamatan Tanah Sepenggal.

Mengingat Pemerintah Kecamatan Tanah Sepenggal sekarang mengadakan lomba yang berkaitan dengan seni tradisional. Maka peneliti tertarik untuk mengkaji dan meneliti lebih seksama tentang Upaya Pemerintah Kecamatan tersebut. Hasilnya disajikan kedalam Skripsi dengan judul: "UPAYA PEMERINTAH KECAMATAN DALAM MELESTARIKAN SENI TRADISIONAL ( Studi Seni Tari Dan Musik Tradisional Di Kecamatan Tanah Sepenggal)."

\section{Pembahasan}

Upaya Pemerintah Kecamatan Tanah Sepenggal Dalam Melestarikan Seni Trdisional

Dalam Upaya Melestarikan Seni Tradisional Pemerintah Kecamatan Tanah Sepenggal perlu mengadakan kerja sama dengan masyarakat umumnya masing masing Rio yang ada di Keceamatan Tanah Sepenggal, Tokoh Adat, Sanggar Seni dan Tokoh Masyarakat di Kecamatan Tanah Sepenggal. Guna untuk meningkatkan keinginan masyarakat terhadap Seni Tradisional, agar Seni Tradisional tidak di lupakan oleh masyarakat setempat. Dalam hal ini kelompok tersebut telah melakukan program kegiatan yang telah di programkan oleh Pemerintah Kecamatan Tanah Sepenggal untuk mencapai suatu keinginan agar Seni Tradisional tetap terlestarikan, yang mana dengan di bentuknya kegitan tersebut dapat mempertahankan Seni Teradisional yang ada di Kecamatan Tanah Sepenggal. Kegiatan tersebut antara lain adalah sebagai berikut:

\section{Sosialisasi}

Dalam upaya melestarikan Seni Tradisional, Pemerintah Kecamatan Tanah Sepenggal beserta kelompok yang tergabung dalam kegitan ini melakukan sosialisasi ke seluruh desa yang ada di Kecamatan Tanah 
Sepenggal, selain itu mereka juga melakukan sosialisasi kesekolah sekolah yang ada di Kecamatan Tanah Sepenggal seperti SD, SMP, dan SMA/SMK.

Apa yang dilakukan oleh kelompok kegiatan tersebut dapat meningkatkan keinginan masyarakat terhadap Seni Tradisional. Kemudian dari pada itu diharapkan kepada seluruh masyarakat yang ada di Kecamatan Tanah Sepenggal agar terus melestarikan yang namanya Seni Tradisional supaya tidak terlupakan oleh masyarakat Kecamatan Tanah Sepenggal. Kegiatan tersebut didirikan pada tahun 2017, mengingat daerah Kecamatan Tanah Sepenggal yang hampir melupakan yang namanya Seni Tradisional, di karenakan banyak/besarnya peluang seni - seni modern masuk ke daerah Kecamatan Tanah Sepenggal.

Dengan diadakan kegiatan sosialisasi tersebut dapat secara cepat meningkatkan beberapa minat rakyat untuk Melestarikan Seni Tardisional di seluruh desa yang ada di Kecamatan Tanah Sepanggal. Dengan demikian berlansungnya kegiatan tersebut sangat membantu Pemerintah Kecamatan Tanah Sepenggal dalam melestarikan Seni Tradisional. Hasil dari kegiatan tersebut bisa dirasakan lansung oleh masyarakat dan pelajar yang ada di Kecamatan Tanah Sepenggal.

\section{Kegiatan Pentas Seni (PENSI)}

Kegiatan ini dilaksanakan untuk memotivasi atau meningkatkan semangat rakyat terhadap Seni Tradisional, yang mana Pentas Seni (PENSI) tersebut dapat di pertontonkan oleh semua masyarakat dari kalangan manapun umumnya masyarakat Kecamatan Tanah Sepenggal, agar masyarakat yang menyaksikan Pentas Seni (PENSI) tersebut bisa mengetahui indahnya Seni Tradisional yang ada di Kecamatan Tanah Sepenggal.

Perencanaan Pemerintah Kecamatan Tanah Sepenggal untuk melestarikan Seni Tradisional tersebut sangatlah bagus. Dalam hal ini marilah kita bersama - sama Menjaga, Mempertahankan, Meningkatkan dan Melestarikan Seni Teradisional yang ada di Kecamatan Tanah Sepenggal agar tidak terlupakan oleh kita semua. Dengan demikian Budaya atau Seni Tradisional di Kecamatan Tanah Sepenggal ini tetap terjaga, walaupun budaya - budaya atau seni - seni modern terus menerus masuk kedaerah Kecamatan Tanah Sepenggal, itu tidak mempengaruhi hilangnya Seni Tradisional atau Budaya yang ada di Kecamatan Tanah Sepenggal. Dan tidak mengurangi semangat masyarakat untuk terus menerus mempelajari atau Melestarikan Seni Tradisional keanak - anak muda sebagai generasi penerus suatu daerah atau bangsa.

Dengan diadakan acara Pentas Seni tersebut dapat meningkatkan keinginan masyarakat Kecamatan Tanah Sepenggal tehadap Seni Tradisioanl. Dengan melihat beberapa desa yang ada di Kecamatan Tanah Sepenggal yang perlahan-lahan sudah mulai mengaktifkan Seni Tradisional di desanya masing-masing, dengan demikian acara yang diadakan oleh Pemerintah Kecamatan Tanah Sepenggal sudah bisa dikatakan cukup berhasil dalam Melestarikan Seni Tradisional.

3. Mengadakan Pelatihan Seni Tradisional Di Kantor Camat Kecamatan Tanah Sepenggal

Dalam kegitaan ini Pemerintah Kecamatan Tanah Sepenggal meminta kepada seluruh desa yang ada di Kecamatan Tanah Sepenggal untuk 
mengikuti pelatihan tersebut. Setidaknya 1 (satu) atau 2 (dua) orang saja sebagai perwakilan dari desa masing - masing untuk mengikuti pelatihan yang di adakan oleh Pemerintah Kecamatan Tanah Sepenggal.

Pelatihan yang diadakan oleh Pemerintah Kecamatan Tanah Sepenggal untuk Mempertahankan, Meningkatkan atau Melestarikan Seni Tradisional sangatlah bagus. Dengan Pemerintah Kecamatan Tanah Sepenggal mengadakan pelatihan tersebut, perangkat desa yang mengikuti pelatihan ini dapat menjalurkan atau dapat ikut serta melestarikan Seni Tradisional di desanya masing - masing. Dengan demikain Pemerintah Kecamatan Tanah Sepenggal merasa terbantu oleh seluruh perang desa yang mengikuti pelatihan tersebut dalam Melestarikan Seni Tradisonal di Kecamatan Tanah Sepenggal.

Kegiatan yang dilakukan oleh Pemerintah Kecamatan Tanah Sepenggal sangat bagus yaitu bertujuan untuk Melestarikan Seni Tradisional, agar masyarakat atau perangkat desa yang mengikuti Pelatihan Seni Tradisional ini dapat menerapkan apa yang iya dapatkan selama pelatihan tersebut di desanya masing-masing, terutama kepada muda/I sebagai generasi penerus Kecamatan Tanah Sepenggal.

\section{Kendala Kendala Pemerintah Kecamatan Tanah Sepenggal Dalam Melestarikan Seni Tradisional}

Salah satu unsur penting dalam Upaya Melestarikan Seni Tradisional adalah terciptanya kekompakan masyarakat yang stabil sehingga dapat menjalankan semua yang di rencanakan dengan bagus, sebab kekompakan adalah kekuatan yang sangat luar biasa besarnya, yang dapat menciptakan semua keinginan berjalan dengan mulus. Dalam beberapa tahun ini di Kecamatan Tanah Sepenggal mengalami krisis akan Seni Tradisional, yang ditandai dengan meningkatnya seni seni modern masuk ke daerah Kecamatan Tanah Sepenggal. Ketika seni modern mengalami peningkatan di Kecamatan Tanah Sepenggal, masyarakat tidak memperdulikan akan terancamnya Seni Tradisional di Kecamatan Tanah Sepenggal, dikarenakan anggapan masyarakat Seni Tradisional sudah kuno atau sudah ketinggalan zaman, padahal Seni Tradisional adalah peninggalan nenek moyang kita terdahulu. Hal ini dikarenakan kurangnya kepedulian masyarakat terhadap Seni Tradisional sehingga dapat menyebabkan hilangnya seni tradisional di Kecamatan Tanah Sepenggal.

Dalam meningkatkan pelestarian Seni Tradisional di Kecamatan Tanah Sepenggal diantaranya sebagai berikut:

1. Minimnya Kurangnya Kerjasama Masyarakat

Dalam meningkatkan Pelestarian Seni Tradisional nampaknya keterlibatan masyarakat belum bisa dirasakan sepenuhnya oleh Pemerintah Kecamatan Tanah Sepenggal. hal itu terjadi dikarenakan masih kurangnya kepedulian masyarakat terhadap Seni Tradisional, dan masyarakat memiliki anggapan bahwa Pemerintah Kecamatan Tanah Sepenggal lah yang bertanggung jawab dalam Melestarikan Seni Tradisional tersebut. Padahal semua masyarakat Kecamatan Tanah Sepenggal ini mempunyai peran untuk menjaga atau melestarikan Seni Tradisional, sebab itu adalah peninggalan nenek moyang kita bersama.

Dalam Melestarikan Seni Tradisional Pemerintah Kecamatan Tanah Sepenggal sangat membutuhkan kerjasama masyarakat sehingga kegiatan tersebut bisa terlaksana dengan baik. Dengan demikian beberapa hal yang menjadi kendala Pemerintah Kecamatan Tanah Sepenggal dalam Melestarikan Seni Tradisional itu masih menjadi kendala yang berat dikarenakan kurangnya kerjasama 
masyarakat dengan Pemerintah Kecamatan Tanah Sepenggal. masyarakat lebih mementingkan kehidupan pribadi dari pada kehidupan bermasyarakat.

Harapan Pemerintah Kecamatan Tanah Sepenggal terhadap keterlibatan masyarakat dalam Melestarikan Seni Tradisional itu sangat besar, hal ini tidak menutup kemungkinan akan membantu Pemerintah Kecamatan Tanah Sepenggal dalam Melestarikan Seni Tradisional. Dengan adanya kerjasama masyarakat terhadap Pemerintah Kecamatan Tanah Sepenggal itu mungkin bisa membantu memudahakan untuk Melestarikan Seni Tradisional yang ada di Kecamatan Tanah Sepenggal.

Dalam hal ini Pemerintah Kecamatan Tanah Sepenggal sebagai manusia biasa juga memiliki kemampuan yang terbatas dalam Melestarikan Seni Tradisional di Kecamatan Tanah Sepenggal. Hal itu tidak dapat diatasi semua oleh Pemerintah Kecamatan Tanah Sepenggal, dikarenakan kurangnya kerjasama masyarakat dalam Melestarikan Seni Tradisional, dengan besarnya kesempatan Seni Modern masuk ke daerah Kecamatan Tanah Sepenggal, dengan itu pula lah Pemerintah Kecamatan Tanah Sepenggal sanggat - sangat membutuhkan kerjasama masyarakat, dikarenakan sudah banyak sekali masyarakat Kecamatan Tanah Sepenggal yang hampir melupakan Seni Tradisional, hal ini di sebabkan masyarakat Kecamatan Tanah Sepenggal menganggap Seni Modern yang masuk ke daerah Kecamatan Tanah Sepenggal saat ini jauh lebih Kren di bandingkan Seni Tradisional yang sudah ketinggalan zaman (Jadul). Pemerintah Kecamatan Tanah Sepenggal menghimbau kepada seluruh masyarakat ada di Kecmatan Tanah Sepnggal untuk berkerjasama dalam Melestarikan Seni Tradisional, anak - anak atau muda/I sangat membutuhkan bimbingan dalam mengenal Seni Tradisional, jika anak - anak atau muda/I tidak mengenal yang namanya Seni Tradisional siap yang akan meneruskan atau mengembangkan Seni Tradisional di daerah Kecamatan Tanah Sepenggal. kalu bukan kita yang mengajarkan anak - anak atau muda/I untuk mengenal yang namanya Seni Tradisional itu siapa lagi, kalau bukan sekarang kapan lagi.

2. Kurangnya Fasilitas Alat Seni Tradisional

Minimnya fasilitas alat seni tradisional tersebut juga menjadi kendala masyarakat atau pemerintah kecamatan tanah sepenggal dalam melestarikan seni tradisional, dengan ini hambatan tersebut kinerja pemerintah kecamatan tanah sepenggal belum terlaksana dengan baik. Fasilitas yang tidak memadai tersebut seperti alat - alat music untuk melestarikan seni tradisional.

Apa yang menjadi kendala tersebut membuat kegiatan Pemerintah Kecamatan Tanah Sepenggal dalam Melestarikan Seni Tradisional belum bisa berjalan dengan maksimal sebagai mana mestinya. Mungkin dalam penanganan hal tersebut butuh alat - alat music yang cukup untuk mencapai sesuai yang di harapkan oleh Pemerintah Kecamatan Tanah Sepenggal seperti Melestarikan Seni Tradisional. Sedangkan hal yang di butuhkan untuk Melestarikan Seni Tradidisonal itu adalah alat - alat musicnya, nah bagaimana keinginan Pemerintah Kecamatan Tanah Sepenggal agar minat masyarakat menigkat terhadap Seni Tradisional jika alat - alat musicnya masih minim. 
Dengan demikian, dalam keadaan kurangnya fasilitas tersebut Pemerintah Kecamatan Tanah Sepenggal terus berupaya untuk Melestarikan Seni Tradisional. Dan dengan apa yang telah dilakukan oleh Pemerintah Kecamatan Tanah Sepenggal bisa berjalan walaupun masih ada beberapa kendal yang menjadi halangan dan rintangan Pemerintah Kecamatan Tanah Sepnggal tersebut. Dengan berjalannya kegiatan tersebut pihak Pemerintah Kecamatan Tanah Sepenggal sangat berharap pihak - pihak yang terlibat untuk membantu dalam menutupi kekurangan yang menjadi kendala dalam Melestarikan Seni Tradisonal. Dan disamping itu apa yang dilakukan oleh Pemerintah Kecamatan Tanah Sepenggal dikit demi sedikit sudah mulai menigkatkan minat rakya terhadap Seni Tradisional walaupun itu masih jauh dari kata sempurna. Dalam hal ini Pemerintah Kecamatan Tanah Sepenggal akan selalu berupaya untuk Melestarikan Seni Tradisional Di Kecamatan Tanah Sepenggal. Dengan apa yang dilakukan oleh Pemerintah Kecamatan Tanah Sepnggal itu semata mata karena ingin memberikan yang terbaik kepada masyarakat Kecamatan Tanah Sepengal, namun dalam hal ini Pemerintah Kecamatan Tanah Sepenggal tersebut sudah berusaha sebaik - baik mungkin dalam Melestarikn Seni Tradisional.

Hal yang menjadi kendala pemerintah kecamatan tanah sepenggal dalam melestarikan seni tradisional di seluruh desa yang ada di kecamatan tanah sepenggal itu ialah minim nya alat musik seni tradisional di desa-desa yang ada di kecamatan tanah sepenggal dapat menurun kan minat masyarakat dalam melestarikan seni tradisional.

3. Pembinaan Seni Tradisional Di Kecamatan Tanah Sepenggal Yang Belum Maksimal

Dalam hal ini tidak berjalannya Seni Tradisional di Kecamatan Tanah Sepenggal mungkin juga menjadi hambatan Pemerintah Kecamatan Tanah Sepenggal dalam Melestarikan Seni Tradisional. Yang menjadi kendala besar dalam Melestarikan Seni Tradisional tersebut adalah tidak adanya anggaran yang mendukung bagi para Pelestarian Seni Tradisional tersebut. Hal itu membuat kegiatan Pelestarian Seni Tradisional tidak berjalan sebagaimana mestinya. Dan selain itu kurangnya kerja sama masyarakat dalam melakukan Pelestarian Seni Tradisional, dalam hal ini masyarakat perlu kebersamaan untuk melakukan Pelestarian Seni Tradisional di desanya masing - masing, sebab dengan adanya kebersamaan masyarakat tersebut dikit demi sedikit Pelestarian Seni Tradisional di Kecamatan Tanah Sepenggal mungkin bisa berjalan dengan sesuai yang di harapkan oleh Pemerintah Kecamatan Tanah Sepenggal.

Hal ini perlu kita ketahui bahwa Seni Tradisional sangat lah penting untuk kita jaga atau kita lestarikan, sebab Seni Tradisional ini adalah salah satu warisan atau peninggal nenek moyang kita terdahulu yang turun-temurun hinggal saat sekarang ini. Oleh karena itu kita selaku warga Kecamatan Tanah Sepenggal melihat bahwa di Kecamatan Tanah Sepenggal ini sangatlah minim masyarakat yang memperdulikan Seni Tradisional yang dikenal sebagai warisan atau peninggal nenek moyang kita terdahulu, maka dari itu marilah kita berkerja sama untuk meningkatkan minat rakyat terhadap Seni Tradisional. Dan hal tersebut juga menjadi tugas Pemerintah Kecamatan Tanah Sepenggal dalam Melestarikan Seni Tradisional, dan pihak Pemerintah Kecamatan Tanah Sepenggal harus berupaya untuk Melestarikan Seni Tradisional sehingga kegiatan Pelestarian 
Seni Tradisional tersebut bisa memberikan suatu dampak yang baik. Dalam hal ini Pemerintah Kecamatan Tanah Sepenggal harus lebih aktif dalam kerja sama dengan Pemerintah Desa agar Pelestarian Seni Tradisional di Kecamatan Tanah Sepenggal bisa dengan cepat tersebar luas keseluruh pelosok yang ada di Kecamatan Tanah Sepenggal. selain itu Pemerintah Desa juga dalam hal ini harus mengetahui penyebab kurang berjalannya kegiatan Pelestarian Seni Tradisional di desanya masing-masing, dan Pemerintah Desa harus cepat-cepat mengambil langkah untuk menjadikan kegiatan Pelestarian Seni Tradisional ini sebagai kegiatan yang disukai masyarakat. System Pelestarian Seni Tradisional adalah salah satu kegitan yang dilakukan secara kerja sama antara Pemerintah Kecamatan Tanah Sepenggal, Masyarakat dan Pemerintah Desa.

Dalam melakukan upaya pembinaan terhadap masyarakat yang tidak peduli dengan Seni Tradisional, Pemerintah Kecamatan Tanah Sepenggal melakukan penyuluhan, penerangan, komunikasi atau berbagai macam kegiatan lainnya. Dalam pembinaan ini Pemerintah Kecamatan Tanah Sepenggal harus bersikap proaktif, tidak menunggu dari masyarakat, karena kehidupan masyarakat sekarang ini khususnya Masyarakat Kecamatan Tanah Sepenggal sudah mengalami pergeseran, sudah tidak saling peduli antar sesama tidak mau tau apa yang terjadi disekitar. Ini merupakan tugas yang berat bagi Pemerintah Kecamatan Tanah Sepenggal untuk Melestarikan Seni Tradisional di Era Modern seperti saat ini.

Dalam melakukan Pelestarian Seni Tradisional Pemerintah Kecamatan Tanah Sepenggal tidak berhenti dari banyaknya kendala. Kendala tersebut karena kurangnya keterlibatan masyarakat dan pihak-pihak yang terkait. Dengan demikian apa yang telah dilakukan Pemerintah Kecamatan Tanah Sepenggal sudah memberikan yang terbaik untuk Masyarakat Kecamatan Tanah Sepenggal. dalam hal ini Pemerintah Kecamatan Tanah Sepenggal tidak berhenti-henti meminta kepada masyarakat untuk selalu berkerja sama sehingga apa yang menjadi tugas bersama ini bisa terlaksana dengan baik. Kemudian dari pada itu Pemerintah Kecamatan Tanah Sepenggal akan selalu berupaya untuk meningkatkan pelestarian terhadap Seni Tradisional, dengan adanya Pelestarian Seni Tradisional tersebut itu sangat dirasakan oleh sebagian masyarakat.

Kemudian dari pada itu, banyaknya kendala dalam melakukan Pelestarian Seni Tradisional, Pemerintah Kecamatan Tanah Sepenggal tersebut telah berhasil walaupun keberhasilan tersebut belum bisa dirasakan semaksimal mungkin oleh masyarakat. Dengan apa yang telah dilakukan Pemerintah Kecamatan Tanah Sepenggal tersebut itu bisa meningkatkan minat rakyat terhadap Seni Tradisional yang selama ini hampir dilupakan oleh Masyarakat Kecamatan Tanah Sepanggal, itu berarti kinerja Pemerintah Kecamatann Tanah Sepenggal tersebut dinilai berhasil walaupun masih ada beberapa kendala yang terjadi.

Berdasarkan hasil penelitian diatas, dapat dikemukakan bahwa Pelestarian Seni Tradisional yang di laksanakan oleh Pemerintah Kecamatan Tanah Sepenggal sudah cukup berhasil, walaupun keberhasilan tersebut belum bisa di rasakan semaksimal mungkin oleh sebagian Masyarakat Tanah Sepengal. Namun Pemerintah Kecamatan Tanah Sepenggal tidak lekas puas dengan keberhasilan tersebut, karena Pemerintah Kecamtan Tanah Sepenggal akan terus 
berupaya untuk Melestarikan Seni Teradisional di Kecamatan Tanah Sepenggal, agar seluruh Masyarakat Tanah Sepenggal benar-benar mempedulikan Seni Tradisional yang dikenal sebagai peninggalan atau warisa nenek moyang kita terdahulu.

Pemerintah Kecamatan Tanah Sepenggal sangat membutuhkan kerja sama antar masyarakat untuk Melestarikan Seni Tradisional, dikarenakan tanpa ada kerja sama antar masyarakat Upaya Pemerintah Kecamatan Tanah Sepenggal untuk Melestarikan Seni Tradisional ini akan sulit berjalan sesuai yang diigikan oleh Pemerintah Kecamatan setempat. Maka dari itu saya selaku peneliti sekaligus masyarakat Kecamatan Tanah Sepenggal berharap kepada masyarakat dapat berkerja sama dengan baik untuk Melestarikan Seni Tradisional di kecamatan kita ini, dikarenakan Pemerintah Kecamatan sangat membutuhkan kekompakan kita bersama selaku masyarakat Kecamatan Tanah Sepenggal untuk Melestarikan Seni Tradisional, sebab kerja yang berat akan terasa lebih ringan apabila kita bisa berkerja sama dengan baik.

\section{Upaya Pemerintah Kecamatan Tanah Sepenggal Menyelesaikan Hambatan Yang Ada Dalam Melestarikan Seni Tradisional}

Tugas besar memang akan menjadi lebih ringan, lebih cepat, serta lebih efektif apabila dilakukan bersama. Kegiatan Melestarikan Seni Tradisional bukan hanya tugas dari para pejabat Pemerintah Kecamatan Tanah Sepenggal saja, tapi juga tugas kita semua. Warga sebagai elemen penting juga harus ikut serta dalam meningkatkan atau Melestarikan Seni Tradisional di Kecamatan Tanah Sepenggal. Kita harus mempersempit ruang lingkup Seni Modern untuk masuk kedaerah Kecamatan Tanah Sepenggal.

Kegiatan sosialisasi yang dilaksanakan oleh Pemerintah Kecamatan Tanah Sepenggal untuk mempersempit ruang lingkup Seni Modern masuk kedaerah Kecamatan Tanah Sepenggal sangat lah efektip. Dengan cara ini lah Seni Tradisional bisa terlestarikan dengan baik, dikarenakan anak-anak atau muda/I adalah salah satu Asset yang sangat besar sebagai generasi penerus bangsa atau generasi penerus suatu daerah, kalau bukan anak-anak atau muda/I siapa lagi, kalau bukan sekarang kapan lagi. Dari itu lah sang peneliti sangat mengharapkan kegiatan Pelestarian Seni Tradisional yang ada di Kecamatan Tanah Sepenggal ini akan terus terlaksana untuk tahun-tahun yang akan datang.

\section{Kerjasama Antar Masyarakat}

Ternyata kekompakan itu mempunyai peran yang cukup besar dalam Melestarikan Seni Tradisional, kita tidak boleh tergantung oleh tenaga Pemerintah Kecamatan Tanah Sepenggal yang ada, mari kita mempersempit ruang lingkup Seni Modern yang masuk ke Kecamatan Tanah Sepenggal, agar Seni Tradisional yang ada di Kecamatan Tanah Sepenggal ini tidak di lupakan oleh masyarakat setempat. Terutama anak - anak muda yang terlalu menggemari seni - seni modern yang sudah berada di Kecamatan Tanah Sepenggal.

Ada beberapa kebijakan yang telah di tetapakan oleh masyarakat Kecamatan Tanah Sepenggal guna untuk Mempertahankan, Meningkatkan, Melestarikan Seni Tradisional di Kecamatan Tanah Sepenggal, diantaranya sebagai berikut:

1. Mengaktifkan kembali Seni Tradisional di desa masing - masing, guna untuk meningkatkan pelestarian Seni Tradisional yang ada di Kecamatan Tanah Sepenggal.

2. Mempersempit ruang lingkup Seni Modern yang ada di Kecamatan Tanah Sepenggal, agar Pelestarian Seni Tradisional berjalan sesuai yang di inginkan 
3. Tokoh Agama dan Tokoh Masyarakat secara aktif melaksanakan Pelestarian Seni Tradisional, agar Seni Tradisional tidak dilupakan oleh masyarakat Kecamatan Tanah Sepenggal

2. Sosialisasi

Hal ini adalah kebijakan yang di ambil oleh Pemerintah Kecamatan Tanah Sepenggal dalam menyelesaikan hambatan yang ada yaitu melakukan kerja sama untuk Melestarikan Seni Tradisional. Nampakya kebijakan tersebut sudah mulai berjalan, peran pemerintahan desa atau dusun dalam melaksanakan kebijakan ini dikit demi sedikit sudah mulai berjalan walaupun itu cuma beberapa desa saja yang baru menjalankan kebijakan tersebut.

Dengan kebijakan tersebut Pemerintah Kecamatan Tanah Sepenggal merasa terbantu dalam Melestarikan Seni Tradisional, dengan ini pula lah tugas - tugas Pemerintah Kecamatan Tanah Sepenggal sudah mulai berkurang, dikarenakan beberapa desa yang ada di Kecamatan Tanah Sepenggal sudah mulai menjalankan kebijakan yang telah di tetapkan oleh Pemerintah Kecamatan Tanah Sepenggal.

\section{Penutup}

Berdasarkan hasil penelitian yang telah dilakukan di Pemerintah Kecamatan Tanah Sepenggal Kabupaten Bungo maka dapat ditarik bahwa: (1) Upaya Pemerintah Kecamatan Tanah Sepenggal dalam Melestarikan Seni Tradisional antara lain sebagai berikut:a. Melaksanakan kegiatan Sosialisasi untuk Melestarikan Seni Tradisional, kegiatan Sosialisasi ini di laksanakan setiap Desa atau Sekolah yang ada di Kecamatan Tanah sepenggal. b. Melaksanakan kegiatan Pentas Seni (PENSI) yang mungkin dapat meningkatkan pelestarian Seni Tradisional. Kegiatan tersebut dilaksanakan tepatnya di Pasar Lubuk Landai Kecamatan Tanah Sepenggal. c. Melaksanakan pelatihan Seni Tradisional yang di laksanakan di Kantor Camat Kecamatan Tanah Sepenggal. Pelatihan ini dilaksanakan untuk perangkat - prangkat desa yang ada di Kecamatan Tanah Tanah Sepenggal, agar perangkat desa yang mengikuti pelatihan tersebut menjalurkan apa yang di ajarkan oleh Pemerintah Kecamatan Tanah Sepenggal ke masyarakat yang ada di desanya masing - masing. (2) Kendala yang dihadapi oleh Pemerintah Kecamatan Tanah Sepenggal dalam Melestarikan Seni Tradisional antara lain sebagai berikut: a. Kurangnya partisipasi masyarakat dalam meningkatkan pelestarian Seni Tradisional yang telah di terapkan oleh Pemerintah Kecamatan Tanah Sepenggal, dan masyarakat menganggap bahwa tanggung jawab dalam melestarikan Seni Tradisional tersebut itu semua di bebankan ke pihak Pemerintah Kecamatan Tanah Sepenggal saja, padahal untuk Melestarikan Seni Tradisional tersebut itu bisa dilakukan oleh siapa saja, tidak di haruskan Pemerintah Kecamatan itu sendiri yang Melestarikan Seni Tradisional, seluruh masyarakat Kecamatan Tanah Sepenggal itu bisa untuk Melestarikan Seni Tradisional selagi mereka ada kemauan. b. Tidak berjalan semaksimal mungkin kegiatan Pelestarian Seni Tradisional di desa - desa yang ada di Kecamatan Tanah Sepenggal, dikarenakan alat music yang di miliki oleh desa - desa yang ada di Kecamatan Tanah Sepenggal itu sangat minim. Hal ini membuat masyarakat merasa enggan untuk melakukan Pelestarian Seni Tradisional tersebut. (3) Upaya Pemerintah Kecamatan Tanah Sepenggal Menyelesaikan Hambatan Yang Ada Dalam Melestarikan Seni Tradisional: a. kegiatan sosialisasi yang dilaksanakan oleh Pemerintah Kecamatan Tanah Sepenggal sangat lah Efektip dan Efisien dalam Melestarikan Seni Tradisional, dengan kegitan sosialisasi ini lah Seni Tradisional yang ada di Kecamatan Tanah Sepenggal bisa Terlestarikan dengan Efektip dan Efisien. b. ternyata kerjasama anatar masyarakat sangat di butuhkan dalam setiap 
kegiatan, terutama kegiatan Pelestarian Seni Tradisional yang di selenggarakan oleh Pemerintah Kecamatan Tanah Sepenggal baru-baru ini. Tanpa ada kerjasama antar masyarakat atau antar anggota Pelestarian Seni Tradisional tidak akan bisa terlestarikan dengan Efektif.

Dari kesimpulan peneliti diatas, penulis menyarankan sebagai berikut: 1 . Diharapkan kepada seluruh masyarakat Kecamatan Tanah Sepenggal marilah berkerja sama dalam melestarikan Seni Tradisional, dan tidak diharuskan Pemerintah Kecamatan itu sendiri yang akan melestarikan Seni Tradisional, kita selaku warga masyarakat Kecamatan Tanah Sepenggal harus ikut serta dalam melestarikan Seni Tradisional, agar pelestarian Seni Tradisional bisa terlaksana sesuai dengan apa yang diharapkan Pemerintah Kecamatan Tanah Sepenggal.2. Kepada seluruh desa - desa yang ada di Kecamatan Tanah Sepenggal diharapkan untuk lebih mengaktifkan Seni - Seni Tradisional yang ada di desanya masing masing, agar Seni Tradisional tidak dilupakan oleh masyarakat setempat, dan Seni Tradisional tetap terlestarikan sesuai dengan yang diharapkan Pemerintah Kecamatan Tanah Sepenggal.3. Diharapkan kepada seluruh Pemerintah Kecamatan Tanah Sepenggal atau kepada seluruh Anggota Pelestarian Seni Tradisional ataupun kepada seluruh masyarakat yang ada di Kecamatan Tanah Sepenggal agar terus menerapkan kegiatan Pelestarian Seni Tradisional, agar nantinya Seni Tradisional yang ada di Kecamatan Tanah Sepenggal tidak di lupakan oleh masyarakat setempat, umumnya anak-anak atau muda/I yang sebagai Asset

\section{Referensi} generasi penerus bangsa atau generasi penerus suatu daerah.

Iskandar, J. (2017). Etnobiologi dan keragaman budaya di indonesia. Umbara, 1(1).

Jaya, Mulia. (2014). Krinok sebagai Media Pembelajaran, Muara Bungo.

Nuh, Muhammad.(2014). Seni Budaya, Pusat Kurikulum dan Pembukuan.

Nusantara, Yayat . (2007). Seni Budaya untuk Kelas X. Erlangga.

Putra, Juni. (2015). Proposal Skripsi. Muara Bungo.

Saryono, Mekar Dwi Anggraeni. (2013). Metode Penelitian Kualitatif dan Kuantitatif.

Nurhamedika.

Sugiyono. (2012). Metode Penelitian Administrasi. Alfabeta.

Wijiono, B. E. (2009). Seni Budaya dan Keterampilan. PT TIGA SERANGKAI PUSTAKA MANDIRI.

Wulansari, B. Y. (2017). Pelestarian Seni Budaya Dan Permainan Tradisional Melalui Tema

Kearifan Lokal Dalam Kurikulum Pendidikan Anak Usia Dini. Jurnal INDRIA (Jurnal Ilmiah

Pendidikan Prasekolah Dan Sekolah Awal), 2(1). 